\title{
THE COMPENSATION SCHEME NO ONE ASKED FOR: THE ORIGINS OF ACC IN NEW ZEALAND
}

\author{
Peter McKenzie $Q C^{*}$
}

The vision laid down in the 1967 Royal Commission Report was radical in scope and quickly became controversial. Led by its Chairman, Sir Owen Woodhouse, the Commission presented a series of connected principles to support that vision, drawing from earlier critiques of the common law system in New Zealand and abroad. This paper explores the legal background in New Zealand prior to the Woodhouse Report and reviews prior movement toward reform, including submissions made by members of the Victoria University Law Faculty. It also describes opposition to the Report from members of the bar and other interest groups, but suggests reasons why the Woodhouse framework was nonetheless able to prevail.

In 1969, some 18 months after the Royal Commission had delivered its Report ${ }^{1}$ on Compensation for Personal Injury in New Zealand, a panel discussion on the Report was organised by the New Zealand Law Society. The deliberations of the panel are reported in the New Zealand Law Journal. ${ }^{2}$ The Solicitor-General, Mr J C White QC, and Mr E W Thomas, spoke in favour of the Report and Mr Brian McClelland and Mr W G Clayton represented the opposing position. $\mathrm{Mr}$ White's support for the Woodhouse proposals was significant, having regard to the guarded support given by him as a member of the Committee on Absolute Liability ${ }^{3}$ for a more comprehensive scheme to cover motor vehicle and industrial accidents despite his endorsement of the majority position in this report. The majority had endorsed the status quo.

* Barrister, Wellington.

1 Compensation for Personal Injury in New Zealand: Report of the Royal Commission of Inquiry (Government Printer, Wellington, 1967) [Woodhouse Report].

2 J C White, E W Thomas, B McClelland and W G Clayton "The Woodhouse Report, A Panel Discussion" [1969] NZLJ 297.

3 New Zealand Committee on Absolute Liability Report of the Committee on Absolute Liability (Government Printer, Wellington, 1963) paras 42-43. 
A significant feature of the panel discussion was the overwhelmingly negative view of the Woodhouse Report by those contributors to the panel discussion whose comments have been reported. Apart from the positive contribution from Mr J H Wallace (now Hon Justice Wallace) and muted support from Mr Des Dalgety, the comments were negative. The Rt Hon Sir Alfred North, President of the Court of Appeal, intervened to make it clear that members of the Court of Appeal did not share the views of their colleague Sir Owen Woodhouse, Sir Alfred stating: "To my mind the idea that it [the common law action] is a lottery is a gross exaggeration".

A continuing theme throughout the comments from a number of leading practitioners was that the common law action had been unfairly dealt with in the Report and that the Report had exceeded its terms of reference. Indeed, it was reported that the Hon T P Shand, Minister of Labour, had that morning acknowledged in a media statement that the Commission had exceeded its terms of reference. That concession did not, however, affect government's willingness to receive the Commission's proposals.

Another feature of the comments was that those who opposed the Report claimed that not only did it have little support from practising lawyers with experience in dealing with personal injury litigation, it was also not supported by other interested groups, particularly the trade unions, and the insurance and automobile industries.

On one issue, however, both supporters and critics of the proposed ACC scheme were agreed. The proposals represented the most far-reaching and imaginative piece of social engineering in New Zealand since the passage of the Social Security Act 1938.

How then, despite the absence of any significant societal pressure or supporting lobby groups, did the proposals for a comprehensive system for compensating the victims of personal injury emerge? The purpose of this paper is to examine the origins of the ACC scheme and trace the particular influences which gave rise to the proposals in the Woodhouse Report and to indicate the factors present at that time which gave impetus to the Report. The process of transition from the Woodhouse proposals to the 1972 legislation is, however, a matter to be addressed more fully in papers to be presented to the next session.

The topic to be dealt with in this paper will be covered under five principal headings:

- $\quad$ The legal framework for compensating personal injury in New Zealand in 1967.

- $\quad$ The stirrings for reform during the decade prior to 1967.

- $\quad$ The Woodhouse proposals.

- $\quad$ The rationale for the reforms proposed by the Woodhouse Report.

- $\quad$ The impetus for change. 
THE LEGAL FRAMEWORK FOR COMPENSATING PERSONAL INJURY IN NEW ZEALAND IN 1967

At the time of the Woodhouse Report, the common law action for damages provided a remedy where personal injury could be attributed to negligence - what has often been called "fault-based liability". This common law remedy was supplemented by three different statutory systems of compensation:

- The Workers' Compensation Act 1956. This was a system for providing a very basic level of compensation for work-related accidents funded by compulsory insurance on the part of employers.

- The Social Security Act 1964, a consolidation of the earlier Act of 1938 which provided for payment of welfare benefits at a subsistence level to persons who could satisfy the prescribed means test.

- The Criminal Injuries Compensation Act 1963 under which a State-funded payment of compensation was made to the victims of the more serious offences prescribed in the Schedule to that Act. The amount of compensation was related to the actual medical, funeral or other expenses incurred by the victim and the pecuniary loss to the victim as a result of total or partial incapacity for work together with a modest sum on account of pain and suffering. These payments were subject to a statutory ceiling.

In the case of road accidents, the common law system was buttressed by provisions in the Transport Act 1962 first introduced in 1928 which provided for a compulsory levy on all owners of motor vehicles which funded payment of damages through a pooled scheme administered by the insurance companies called the "Third Party Pool". In the case of accidents where in breach of the Act no levy had been paid in relation to the vehicle causing the accident, or in the case of the hitand-run accident where the vehicle owner could not be traced, a claim could be brought against the Third Party Pool as a "Nominal Defendant". In this way, all victims of motor vehicle accidents who could establish fault on the part of the driver of the vehicle, were covered.

It is difficult now, in the ACC era, to appreciate the extent to which common law litigation in personal injury cases occupied the legal profession, the Courts and the trade unions. Most legal offices had a significant "common law" practice involved in the formulation and settlement of personal injury claims. Some 90 per cent of the claims were settled out of Court. ${ }^{4}$ Those which did go to trial were handled by advocates who generally combined this area of practice with the conduct of jury trials in criminal cases. Personal injury dominated the law of negligence. Most of the case law in negligence had arisen out of personal injury litigation. The advent of the ACC system required a new approach to the teaching of negligence in New Zealand law schools. It was difficult

$4 \quad$ Woodhouse Report, above, para 80. 
in compiling Tort in Transition, a casebook produced in 1976, to illustrate the principles of negligence by reference to other than personal injury cases. ${ }^{5}$

The common law action was an important part of the artillery of a trade union when confronting an errant employer, and the adversarial system buttressed the role of the union. In addition, the lump sum damages awarded by the common law was regarded as a worker's right which should not be traded in for a periodic payment. The Woodhouse scheme had later to be compromised by the inclusion of lump sum payments in order to obtain union support. ${ }^{6}$

\section{THE STIRRINGS FOR REFORM DURING THE 1960s}

During the 1960s, New Zealand experienced a growing disquiet regarding the adequacy of the common law and the Workers' Compensation Act as systems for providing compensation in the case of road accidents and industrial accidents.

The strengths of the common law system were the moral basis on which it awarded compensation and the targeting of the damages to the individual circumstances of the plaintiff. Where fault could be established, the injured person had the satisfaction of receiving compensation from the wrongdoer (albeit derived in most cases through the medium of insurance) and of receiving compensation not only for loss of earnings and other pecuniary losses, but also what the law called a "solatium" for the pain and suffering and loss of enjoyment of life arising from the accident.

The weakness of the system was the corollary of its virtue. If no fault could be established, then an innocent accident victim would be without remedy, notwithstanding the severity of the injuries which had been sustained. Similarly, if there had been a substantial degree of contributory negligence, the compensation awarded would be proportionately reduced.

The rigour of the system was reduced by the almost universal use of the jury trial. An experienced advocate could often obtain a sympathy verdict for the accident victim. Although a jury could never be told that the defendant was insured, most juries were well aware of that factor. It was not without some significant anecdotal support that the common law system was described as a "lottery".

Employees who could not establish fault on the part of an employer and so recover at common law were still covered by the Workers' Compensation Act 1956. Payments were, however, pegged

5 Peter D McKenzie, Geoffrey Palmer and Roger Clark Tort in Transition (Fourth Estate Books, Wellington, 1976).

6 A detailed discussion of the views of the various interest groups is provided in Geoffrey Palmer "Compensation for Personal Injury" (1973) A J Comp Law 1, Geoffrey Palmer "Abolishing the Personal Injury Tort System" (1971) 9 Alberta L Rev 169 and Geoffrey Palmer Compensation for Incapacity: A Study of Law and Social Change in New Zealand and Australia (Oxford University Press, Wellington, 1979). 
to a very basic level, being limited to 80 per cent of weekly earnings for a maximum period of six years and being subject in addition to a statutory maximum. In 1967, the maximum capitalised payment over six years which any injured worker could receive was $\$ 7,434$. This was the maximum payment for permanent incapacity. Partial incapacity, which was determined on a schedule basis, could be significantly less. In addition, the system of workers' compensation was administered by private insurers and was affected by the same adversarial approach underlying the common law system.

The Workers' Compensation Scheme had few friends and was the subject of recurrent criticism. Apart from the meagre level of compensation, the scheme had given rise to anomalies in its coverage and in the classification of injuries in the schedule of incapacity. These criticisms provided the immediate pretext for appointing the Woodhouse Commission. In 1966, Hon T P Shand, Minister of Labour in the National Government, set up a Royal Commission to inquire and report on compensation in work related accidents.

\section{ISON - THE FORENSIC LOTTERY}

This growing concern regarding the adequacy of the common law system in providing a just means for compensating personal injury was powerfully articulated by the Canadian author, Terence $\mathrm{G}$ Ison, in his analysis of the common law system under the colourful description The Forensic Lottery. ${ }^{7}$ Ison catalogued the weaknesses of the common law system and what he called the "capricious" and unsatisfactory way in which it provided compensation for the victims of accident and disease and advocated the abolition of the fault system and its replacement by a system of social insurance. He pointed out the wasteful nature of the common law system. A survey conducted by him in England showed that 48.9 per cent of the total amount of money flowing into the system was absorbed by the cost of its administration. The members of the Woodhouse Commission visited Professor Ison and conferred with him and his views were influential, being referred to in at least six places in the Woodhouse Report.

The contribution of Ison to the comprehensive scheme advocated by the Woodhouse Commission should not be overstated. At the conference at which this paper was presented, Sir Owen Woodhouse stated that the basic shape of the proposals in the Report had already been formulated before Sir Owen encountered Professor Ison's text.

Other academic criticisms of fault liability also influenced the Woodhouse Commission, in particular Dr D R Harris' advocacy of a comprehensive scheme for road accidents at the New Zealand Law Society Conference in $1963 .^{8}$

7 Terence G Ison The Forensic Lottery (Staple Press, London, 1967).

8 Donald R Harris "The Law of Torts in the Welfare State" [1963] NZLJ 171. 
Another significant academic contribution which debated the future of fault liability was a study made by the law faculty of Osgoode Hall, University of Toronto, referred to in paragraph 153 of the Woodhouse Report. This Report suggested that the claims of plaintiffs are satisfied by the common law process "in inverse proportion to the severity of their injuries", referring to an analysis made of victims of road accidents. Out of a sample of 590 persons, 226 suffered minor injuries and received 71.8 per cent of their losses, whereas 370 suffered serious injuries and received only 32.7 per cent of their losses and the dependants of 57 persons who died received as little as 2.1 per cent. ${ }^{9}$

\section{REPORT OF THE COMMITTEE ON ABSOLUTE LIABILITY}

The precursor to the Woodhouse Commission was the report of the Committee on Absolute Liability given in $1963 .{ }^{10}$ The inconclusive nature of the majority report and the powerful dissenting statement of Mr H R C Wild, then Solicitor-General, opened the door to the Woodhouse Commission to seriously grapple with the introduction of a comprehensive scheme covering both injuries at work and injuries on the road and by extension all other cases of personal injury by accident.

The Committee on Absolute Liability was asked to examine and report to the Minister of Justice on the desirability of introducing some form of absolute liability for death or bodily injuries arising out of the use of motor vehicles, including the adequacy and justice of the present law and insurance practice and legal procedure. The majority considered the question of absolute liability in relation to road accidents in only a very general way, regarding this question as one to be considered primarily as a social problem rather than as a legal or insurance question. ${ }^{11}$ In a significant passage at paragraph 40 , the Committee stated: ${ }^{12}$

There is a case for an accident insurance scheme which would cover all persons who are injured in any way without negligence on their part, provided the community can afford to bear the cost on an equitable basis.

The majority concluded at paragraph 46 that it would not be right to introduce a scheme of accident insurance which would benefit only those who suffered accidents in connection with the use of motor vehicles. It would not be equitable to introduce a scheme for the benefit only of that group of victims while leaving unaddressed those who suffer other accidental misfortune, for example, the dependants of a man who is killed by a sudden fall of earth or those of a man struck

9 Report of the Osgoode Hall "Compensation for Victims of Automobile Accidents" (1965) Chap I, 10 and Chap II, 3.

10 New Zealand Committee on Absolute Liability Report of Committee on Absolute Liability (Government Printer, Wellington, 1963).

11 New Zealand Committee on Absolute Liability, above, para 39.

12 New Zealand Committee on Absolute Liability, above, para 40. 
down by a sudden heart attack. Similarly, it would not be equitable to provide a comprehensive scheme for the victims of road accidents and at the same time limit the victims of industrial injuries to the very basic compensation provided by the Workers' Compensation Scheme. The majority concluded: ${ }^{13}$

Without a much more extensive investigation it is unsafe to reach conclusions on this matter because it would be unwise to make fundamental changes in our present system until definite recommendations can be made that such changes will bring improvements. It is clear, however, that to meet the social problems of misfortune which follows accidents, the whole basis of the present system should be reviewed. For example, it is obvious that if actions at common law were to be abolished an alternative scheme based on compensation for all accidents would be on a much more generous scale than if available funds were still required to meet claims for damages based on negligence. On the other hand, such a change could not be introduced unless it could be shown to be adequate, and therefore an equitable alternative.

The logic underlying this "all or nothing" approach drove straight towards the comprehensive scheme advocated by the Woodhouse Report. The majority had cautiously concluded that "without a much more extensive investigation it is unsafe to reach conclusions on this matter". ${ }^{14}$ The Woodhouse Commission undertook that "much more extensive investigation" and used the "all or nothing" approach to support its advocacy of a comprehensive scheme which would cover all accidental injuries.

In advocating this radical approach, the Woodhouse Commission was able to draw influential support from the Solicitor-General's dissenting statement in the Report of the Committee on Absolute Liability. In a strongly worded statement, Mr H R C Wild took the common law approach head on. He referred to "rules of negligence developed in the days of the horse and buggy" not being suited to speedy modern traffic; to the retention of negligence being bad for the administration of justice with the "artificiality produced at a jury trial by the fiction that the defendant is the person named as such rather than his insurer", this being "merely ludicrous if it were not for the tendency to distort the path of justice according to law. A strain is put upon the conscience of jurors". He considered that the negligence jury trial "is hardly worthy of judicial process with its tradition of integrity and candour". After referring to a number of anecdotal situations, Mr Wild concluded: ${ }^{15}$

Cases of this kind show that recovery of damages can depend not on the true facts but on quite irrelevant matters such as the availability of evidence, the impressiveness of a witness, the prejudices of a jury, and sheer good luck. The evidence of chance plays too great a part.

13 New Zealand Committee on Absolute Liability, above.

14 New Zealand Committee on Absolute Liability, above.

15 New Zealand Committee on Absolute Liability, above. 
He took the majority to task for suggesting that until all cases of personal injury could be addressed, nothing should be done. At paragraph 31 he stated: ${ }^{16}$

The strongest argument is that there is no sufficient justification for providing for victims of the road without also providing for those who suffer accidental injury in other departments of everyday life. ... If fault is to be rejected as the basis for liability on the road the aim is to be compensation for misfortune, is there not an equal claim for entitlement in these cases? To this there is no easy answer. But if the basic aim is sound then the fact that all categories of misadventure cannot be provided for at once is not a ground for doing nothing.

\section{THE CONTRIBUTION OF VICTORIA UNIVERSITY LAW FACULTY}

As a former member of the Victoria University Law Faculty, I cannot mention the academic contribution to the thinking of the Woodhouse Commission without making reference to the Law Faculty contribution. I recall being approached by the then Dean, Professor Colin Aikman, shortly after becoming the Faculty's newest recruit, and told that since I was lecturing in the law of torts, the Dean would like me to join the team from the Faculty which was presenting submissions to the Royal Commission. Colin Aikman mentioned that he had been approached by Sir Owen for assistance. The Commission was questioning whether the fault system should be retained and would like assistance in looking at alternative means of providing compensation on a more comprehensive basis, including examination of the administrative and tax implications. The Commission also sought support for a broad interpretation of its terms of reference. Four papers were produced and presented to the Royal Commission in July 1967.

Professor C C Aikman introduced the papers and argued for a comprehensive scheme to cover all forms of accidental injury to challenge New Zealand which "has rather prided herself on being an originator of social welfare policies" to pursue the vision of the American jurist Oliver Wendell Holmes in his major work, The Common Law, ${ }^{17}$ of replacing the fault system with a different system of liability - namely a wide distribution of accident losses over society, without regard to fault. Professor Aikman assured the Commission that its terms of reference were wide enough to allow it to move down this path. After referring to the terms of reference which covered only "incapacity or death arising out of accidents suffered by persons in employment", Professor Aikman stated: 18

16 New Zealand Committee on Absolute Privilege, above, para 31.

17 Oliver Wendell Holmes The Common Law (Belknap Press, Cambridge (Mass), 1963).

18 New Zealand Royal Commission of Compensation for Personal Injury Compensation for Personal Injury in New Zealand: Report of the Royal Commission of Inquiry (Government Printer, Wellington, 1967) para 169 [Woodhouse Report]. 
In so far as it is established that the most effective way of dealing with work-related injuries is to incorporate those injuries in a general compensation or social insurance scheme, the Commission is clearly called upon to recommend accordingly.

My contribution was a paper directed at the question of whether the common law action should be retained and this paper identified, by reference to the academic literature and a number of New Zealand case examples, the inadequacy of the present system. The paper also dealt with the question of whether the scheme should be restricted to the provision of periodic payments.

Professor I L M Richardson (as he then was) ${ }^{19}$ examined the tax factors involved in workers' compensation and by extension the factors which would need to be addressed when considering a comprehensive system of compensation on similar lines.

Mr K J Keith (as he then was) ${ }^{20}$ directed his submissions to the way in which a comprehensive compensation insurance scheme could be administered and the proposals could be developed for the rehabilitation of the disabled and accident prevention. He advocated that the scheme should be administered by the Social Security Department with the use of other government and administrative resources such as the Post Office, the Inland Revenue Department and the Labour Department.

These submissions were referred to by the Woodhouse Commission in paragraph 169 of its report. Apart from the Social Security Department, and some individual submissions, the Law Faculty was the only party to urge on the Woodhouse Commission the logic of a comprehensive scheme.

\section{THE REFORMS PROPOSED BY THE WOODHOUSE REPORT}

Looking back now, it is surprising that a report of such a far-reaching character should have sprung from such a narrow and unpromising brief. The terms of reference were limited to "claims for compensation or damages in respect of persons incapacitated or killed in employment". ${ }^{21}$ No other form of accidental injury was referred to.

It is apparent that the Woodhouse Commission, armed with the reasoning put forward in the recent Report of the Committee on Absolute Liability and fortified by the views coming from the Law Faculty at Victoria University, took the robust view that it was simply not possible to properly address the position of persons incapacitated or killed in employment without examining the whole

19 Subsequently President of the New Zealand Court of Appeal and currently Distinguished Fellow in Law at Victoria University.

20 Currently a Judge of the New Zealand Court of Appeal.

21 Woodhouse Report, above. 
area of accidental injury however caused. It was a bold step but it had logic and recent experience to support it.

The comprehensive approach taken by the Woodhouse Commission did, of course, lead to the drawing of the line in a different place. If all accidental injuries were to be covered, did not logic and equity require all forms of misfortune to be covered. Should not also illness and mental handicap be included? The problem was stated at paragraph 17 of the Report: ${ }^{22}$

It may be asked how incapacity arising from sickness and disease can be left aside. In logic there is no answer. A man overcome by ill health is no more able to work and no less afflicted than his neighbour hit by a car. In the industrial field certain diseases are included already. But logic on this occasion must give way to other considerations.

The Woodhouse Commission saw a "great advantage" in the integration of a comprehensive scheme of accident compensation into the social security framework. An organic structure and unity would be given to the whole process and it would be possible "to exclude entirely the whole out-moded conception of personal liability which has left with the Courts and the law what is no more than an administrative system with a social purpose". ${ }^{23}$

The Commission rejected the introduction of a unified scheme that introduced the same form of flat-rate payments for all victims of misfortune. ${ }^{24}$

Few would accept such a scheme. Nor would it be just ... The only way in which a comprehensive system of compensation could operate equitably is by linking benefits to earning capacity and by taking into account permanent physical disability.

Whether a system for compensating accidental injury could be integrated into the social security system was left by Woodhouse to be considered as possibly the next move in New Zealand but this could only take place if there was an acceptance that there should be some form of income-related benefit as a supplement or modification to the present social security system. Initial interest in that possibility soon waned and 33 years later a very different economic perspective on the provision of social welfare renders the realisation of Woodhouse's "next move" remote.

The Report was presented in disarmingly simple and jargon-free language. It began with a straightforward and succinct description of the need for reform: ${ }^{25}$

22 Woodhouse Report, above, para 17.

23 Woodhouse Report, above, para 249. The same dilemma is highlighted by Patrick S Atiyah Accident Compensation and the Law (Wiedenfeld and Nicolson, London, 1970) Ch 20 and 608-610.

24 Woodhouse Report, above, para 250.

25 Woodhouse Report, above, para 1. A summary of the Report is given by Alexander Szakats "Reform of Personal Injury Compensation: The White Paper on the Woodhouse Report" (1970) 4 NZULR 139. 
The Problem - One hundred thousand workers are injured in industrial accidents every year. By good fortune most escape with minor incapacities, but many are left with grievous personal problems. Directly or indirectly the cost to the nation for work injuries alone now approaches $\$ 50$ million annually.

This is not all. The same work force must face the grave risks of the road and elsewhere during the rest of every 24 hours. Newspapers up and down the country every day contain a bleak record of casualties.

The toll of personal injury is one of the disastrous incidents of social progress, and the statistically inevitable victims are entitled to receive a co-ordinated response from the nation as a whole. They receive this only from the health service. For financial relief they must turn to three entirely different remedies, and frequently they are aided by none.

The negligence action is a form of lottery. In the case of industrial accidents it provides inconsistent solutions for less than one victim in every hundred. The Workers' Compensation Act provides meagre compensation for workers, but only if their injury occurred at their work. The Social Security Act will assist with the pressing needs of those who remain, provided they can meet the means test. All others are left to fend for themselves.

Such a fragmented and capricious response to a social problem which cries out for co-ordinated and comprehensive treatment cannot be good enough. No economic reason justifies it. It is a situation which needs to be changed.

Five general principles were put forward around which the Report was constructed: ${ }^{26}$

- community responsibility;

- comprehensive entitlement;

- $\quad$ complete rehabilitation;

- $\quad$ real compensation;

- $\quad$ administrative efficiency.

On the basis of these principles, a comprehensive scheme was put forward for compensating all accident victims. Again, there can be no better summary than the summary contained in the report itself: $^{27}$

On the basis of the principles outlined, the scheme proposed -

26 Woodhouse Report, above, para 4.

27 Woodhouse Report, above, para 18. 
would provide immediate compensation without proof of fault for every injured person, regardless of his or her fault, and whether the accident occurred in the factory, on the highway, or in the home;

would entitle that person to compensation both for permanent physical disability and also for income losses on an income-related basis;

would provide for regular adjustment in the level of payment to accord with variations in the value of money;

would provide benefits, if necessary, for life, and in certain circumstances they would be commutable in whole or in part to lump sum payments;

would lift the present weekly maximum rate of compensation to $\$ 120$ and thus safeguard the interests of persons on every normal level of income;

would be geared to urge forward their physical and vocational rehabilitation;

and in all these ways it would provide them with effective insurance for all the risks of the day. If the scheme can be said to have a single purpose it is 24-hour insurance for every member of the work force, and for the housewives who sustain them.

The Woodhouse Report in Chapter XXVI provided an analysis of the funding required for this new scheme which indicated that the removal of the expensive common law system could lead to significant cost savings and meant that the overall cost of the proposed comprehensive scheme represented an increase of only 14.2 per cent. ${ }^{28}$ The funds provided for the present system by way of insurance, motor vehicle levies and Social Security and Health Department funding totalled $\$ 36.6$ million. The estimated funding for the proposed scheme was $\$ 41.8$ million.

The Woodhouse Commission had the foresight to reject overtures from the Social Welfare Department to administer the compensation scheme. This could have compromised the integrity of the scheme. The Commission recommended setting up an independent Authority with an internal review and appeal structure. Insurance companies were also to be excluded, an area where compromise was later needed ${ }^{29}$. The Commission did not, however, wish the Independent Authority it proposed to be an orphan within the Government system. It recommended that the Authority should operate within the general responsibility of the Minister of Social Security and be attached to the Social Security Department for administrative purposes. That recommendation was not followed.

28 Woodhouse Report, above, para 465.

29 Woodhouse Report, above, paras 306-308. 


\section{THE RATIONALE FOR THE REPORT}

The reasons for the Report are succinctly set out by Sir Owen Woodhouse in an illuminating review first provided by Sir Owen in $1977^{30}$ when the legislation had already been in operation for some five years. Three principal reasons were put forward for the recommendations which had been made by the Royal Commission: ${ }^{31}$

(1) The negative argument. The systems already operating in the field were inadequate; unfair; very limited in operation; ignored or even impeded rehabilitation and were expensive.

(2) Community responsibility. The responsibility for accidents is not only the responsibility of the individual who caused the accident. Society itself has built up and encouraged heavily risk-laden activities that exact a known and expected cost in life and limb. It is imperative therefore that society share in the burden that falls in so random a way upon those who become the casualties of activities undertaken for the convenience and utility of society.

(3) Equity. Once society as a whole has accepted the need to support certain groups of injured persons, equity requires that all should be included. The essential principle of community responsibility carries with it as a natural corollary the equitable principle of comprehensive entitlement.

It is significant that in presenting a paper five years after the introduction of the scheme, Sir Owen was able to claim that the new scheme was operating well within its budget and had indeed been able to make savings from reserves of no less than $\$ 172.9$ million: ${ }^{32}$

The Royal Commission Report of 1967 contained a cost analysis which showed (despite the gloomy predictions of many soothsayers) that the wide-ranging proposals put forward could properly be implemented for no more than the funds already required by the far more limited and outmoded systems which were to be replaced ... Unquestionably the estimates of 1967 were, if anything, over-cautious ... The accident compensation scheme in the five years of its operation to 1979, has been able to make savings for reserves of no less than $\$ 172.9$ million.

Furthermore, I am in no doubt that the present income of the Commission is more than sufficient to meet all current claims and still leave ample in hand to be added on any reasonable grounds of prudence to any sensible contingency reserves.

30 Sir Owen Woodhouse "Aspects of the Accident Compensation Scheme" [1979] NZLJ 395.

31 Sir Owen Woodhouse, above, 396.

32 Sir Owen Woodhouse, above, 397-398. 
Given that optimism in 1979, what went wrong? I will need to leave that question to later commentators.

\section{THE IMPETUS FOR REFORM}

To a young idealist at the time, the Woodhouse proposals seemed the obvious and only logical and equitable path forward. Looking back after 33 years the comprehensive scheme recommended by the Woodhouse Commission seems to have been far from inevitable. The Commission's terms of reference were narrow. There was no expectation on the part of government that the Commission would bring forward such a far-reaching report. There were no pressure groups within society pushing for such an outcome. Those who advocated sectional interests looked for no more than an extension or improvement of the existing machinery.

The weaknesses of the common law and workers' compensation systems were apparent but financial prudence, common sense and, in the case of the legal profession and the trade unions, sectional self-interest favoured retention of the lump sum Court-administered process for dealing with the major cases of personal injury.

It required a bold and imaginative Commission to step outside the confines of limited expectation and challenge government, the professions and the New Zealand public to the realisation that a logically constructed scheme to replace the manifest inequities and inadequacies of the present system could be achieved. It was the simple coherence and attractiveness of the Woodhouse concept which in the end muted the criticism of its opponents. The scheme which no one asked for had an impetus of its own. 